\title{
Effects of vaginal-cervical stimulation in seven species of muroid rodents
}

\author{
Ann McM. Kenney, D. L. Lanier and D. A. Dewsbury \\ Department of Psychology, University of Florida, Gainesville, \\ Florida, 32611, U.S.A.
}

\begin{abstract}
Summary. Six species of muroid rodents (Peromyscus californicus, $\boldsymbol{P}$. eremicus, $\boldsymbol{P}$. gossypinus, Mesocricetus auratus, Rattus norvegicus and $R$. rattus) were given artificial vaginal-cervical stimulation in an attempt to induce pseudopregnancy. Some females of each species became pseudopregnant, but it was not clear that stimulation patterns mimicking the copulatory patterns of conspecific males were more effective than other patterns of stimulation. In the non-domesticated species (Peromyscus and $R$. rattus) a few females responded to a variety of stimulus conditions, and no species differences in responsiveness among the wild species were evident. The established laboratory rodents ( $R$. norvegicus, $M$. auratus) were markedly more responsive to artificial stimulation, suggesting possible effects of domestication on fecundity and reactions to handling. Microtus ochrogaster, an induced ovulator, ovulated in response to vaginalcervical stimulation only if one intromission from a male was also provided. No other differences in the responses of reflex and spontaneous ovulators were apparent.
\end{abstract}

\section{Introduction}

Copulatory stimulation is critical for the initiation of neuroendocrine reflexes essential to the establishment of pregnancy in a variety of rodent species, and Diamond (1970) proposed the notion of a 'vaginal code' wherein the female is maximally responsive to patterns of stimulation that mimic the species-typical male copulatory pattern.

Laboratory rats (Rattus norvegicus), roof rats ( $R$. rattus), golden hamsters (Mesocricetus auratus) and cotton mice (Peromyscus gossypinus) all display copulatory patterns in which a group of brief mounts, each with a single vaginal thrust/intromission, precede a mount with intromission and ejaculation. Several series of intromissions with terminal ejaculations occur in a typical mating session (Beach \& Jordan, 1956; Beach \& Rabedeau, 1959; Estep, 1975; D. V. Lovecky, personal communication). In contrast, cactus mice ( $P$. eremicus), California mice $(P$. californicus) and prairie voles ( $M$. ochrogaster) display multiple vaginal thrusts/intromission (Gray \& Dewsbury, 1973; Dewsbury, 1974a,b). None of these 7 species exhibits locking during copulation, and all ejaculate several times in one copulatory episode. Only California mice and cotton mice have been observed to ejaculate at the first intromission, and only prairie voles are induced ovulators (Richmond \& Conaway, 1969). Females of the species in which males display little persistence of copulatory activity and few ejaculatory series have low thresholds for pregnancy initiation relative to the females of species with more persistent males (Davis, Gray, Zerylnick \& Dewsbury, 1974; Gray, Zerylnick, Davis \& Dewsbury, 1974; Dewsbury \& Estep, 1975; Estep, 1975; Lanier, Estep \& Dewsbury, 1975; Davis, Gray \& Dewsbury, 1976; Dewsbury \& Lanier, 1976).

Pseudopregnancy, defined as a functional luteal phase in a non-pregnant cycle (see Conaway, 1971), can be initiated in laboratory rats by a wide range of patterns of artificial stimulation (Long \& Evans, 1922; De Feo, 1966), but the effective stimulus parameters are more limited in golden hamsters (Diamond \& Yanagimachi, 1968) and house mice (Diamond, 1970). Although mechanical stimulation can induce pseudopregnancy in Microtus agrestis, it is effective only in conjunction with copulation- or hormone-induced ovulation.

The purpose of the present research was to explore the range of stimulus patterns effective in 
triggering ovulation and/or a functional luteal phase in females of various species. Artificial stimulation was used and the following features were considered: (1) degree of spontaneity of ovulation, (2) degree of domestication, (3) correlation of most effective stimulus with species-typical male copulatory pattern, (4) threshold related to persistence of male (see above), and (5) possible facilitatory effects of minimal copulatory activity.

\section{Methods and Results}

All females were laboratory born and reared and at least 90 days old. They were individually housed and had food and water available at all times. Rooms were maintained on reversed $16 \mathrm{~h}$ light: $8 \mathrm{~h}$ dark photoperiods (14L:10D for cotton mice and hamsters), and artificial stimulation was applied during the dark phase. Daily vaginal smears were taken using a wire loop, except for hamsters which were examined externally only (Orsini, 1961). Artificial stimulation and/or mating was given on the day of pro-oestrus or oestrus (first day of virtual absence of leucocytes in the smear); for hamsters this was done on the day of transparent vaginal mucus. At least 2 regular vaginal cycles preceded artificial stimulation. Prairie voles, induced ovulators, were stimulated on the 2 nd consecutive day on which they displayed an oestrous smear (over 50\% cornified cells). Stimulation was applied either with a vibratory engraving tool (Sears, Roebuck \& Co., Model 758.42960) fitted with a smooth, moulded 'penis' $3.8 \mathrm{~mm}$ in diameter or with the plunger from a $1.0 \mathrm{ml}$ syringe, $4.5 \mathrm{~mm}$ in diameter. The tip of the stimulator was inserted to the cervix before vibration began.

\section{Experiment I}

Method. Ten cotton mice, 7 cactus mice and 3 California mice were stimulated with the vibrating engraving tool. Stimulus parameters were varied according to the typical copulatory patterns of the 3 species (see Table 1). Cotton mice and cactus mice each received 3 experimental treatments ( 2 cotton mice completed only 2 of these, all cactus mice served twice in each group): (1) one ejaculatory series with a male, (2) artificial stimulation, and (3) one ejaculatory series with a male plus artificial stimulation.

Results. Females were considered pregnant if a litter was born after 21-26 days or pseudopregnant if the vaginal smear remained dioestrous for at least 8 days ( 9 days for California mice). Each pattern of stimulation produced a low incidence of pseudopregnancy or pregnancy, but the response

Table 1. Number of copulations with a male, parameters of artificial stimulation used, and incidence of pseudopregnancy or pregnancy in Peromyscus species

\begin{tabular}{|c|c|c|c|c|c|c|c|}
\hline Species & $\begin{array}{l}\text { No. of } \\
\text { series } \\
\text { with male }\end{array}$ & $\begin{array}{l}\text { No. of } \\
\text { bouts }\end{array}$ & $\begin{array}{l}\text { No. of } \\
\text { insertions/ } \\
\text { bout }\end{array}$ & $\begin{array}{l}\text { Duration } \\
\text { of } \\
\text { insertions } \\
\text { (sec) }\end{array}$ & $\begin{array}{l}\text { Interval } \\
\text { between } \\
\text { insertions } \\
\text { (sec) }\end{array}$ & $\begin{array}{l}\text { Interval } \\
\text { between } \\
\text { bouts } \\
\text { (min) }\end{array}$ & $\begin{array}{l}\text { No. pseudo- } \\
\text { pregnant or } \\
\text { pregnant }\end{array}$ \\
\hline $\begin{array}{l}P . \text { gossypinus } \\
\quad \text { (cotton mice) } \\
(\mathrm{N}=10)\end{array}$ & $\begin{array}{l}1 \\
0 \\
1\end{array}$ & $\begin{array}{l}- \\
1 \\
1\end{array}$ & $\begin{array}{l}- \\
20 \\
20\end{array}$ & $\begin{array}{l}\overline{2} \\
2\end{array}$ & $\begin{array}{l}- \\
5 \\
5\end{array}$ & - & $\begin{array}{l}1 / 9 \\
4 / 10 \\
1 / 9\end{array}$ \\
\hline $\begin{array}{l}\text { P. eremicus } \\
\quad \text { (cactus mice) } \\
(\mathrm{N}=7)\end{array}$ & $\begin{array}{l}1 \\
0 \\
1\end{array}$ & $\begin{array}{l}- \\
2 \\
2\end{array}$ & $\begin{array}{l}\overline{15} \\
15\end{array}$ & $\begin{array}{l}\overline{5} \\
5\end{array}$ & $\begin{array}{l}-\overline{5} \\
5\end{array}$ & $\begin{array}{l}\overline{10} \\
10\end{array}$ & $\begin{array}{l}1 / 14 \\
3 / 14 \\
2 / 14\end{array}$ \\
\hline $\begin{array}{l}\text { P. californicus } \\
\text { (California } \\
\text { mice) } \\
(\mathrm{N}=3)^{*}\end{array}$ & 0 & $2-5$ & 1 & 30 & - & 60 & $4 / 10$ \\
\hline
\end{tabular}

*Two of these mice were stimulated 4 times, the other twice. 
rate was $<40 \%$ in all the treatments. Individual differences in responsiveness among females of a species contributed more to the variation than did the pattern of stimulation. The positive responses were contributed by $4 / 10$ cotton mice, $2 / 7$ cactus mice and $2 / 3$ California mice, each of which responded 2-5 times. Additional attempts to induce pseudopregnancy in California mice by simulating multiple intromissions and multiple ejaculations were unsuccessful. Cactus mice were also tested with vibratory stimuli which simulated intravaginal thrusting and multiple ejaculations, cervical tapping without vibration, or one long continuous vibration, but no pseudopregnancies resulted. One of $5 P$. gossypinus females which received simulation of multiple ejaculations became pseudopregnant, but other stimulus conditions were unsuccessful.

\section{Experiment II}

Method. Five female prairie voles (Microtus ochrogaster) in each of 5 groups were examined for the presence of corpora lutea (CL). In Group 1, voles received artificial stimulation (10 15-sec insertions with 5 thrusts/insertion, and $45 \mathrm{sec}$ between insertions), and were examined on Day 3 after stimulation. In Group 2, voles received $15 \mathrm{sec}$ of flank stimulation (Komisaruk, 1974) before each vaginal-cervical stimulation, which was as in Group 1, and were examined on Day 3. Females in Group 3 received one intromission from a male, no artificial stimulation and examination on Day 3. Group-4 females received one intromission from a male, artificial stimulation as in Group 1 and were examined on Day 3. In Group 5 females were treated as in Group 4, except that CL counts were made on Day 8 instead of Day 3. The reduction in CL number from Day 3 to Day 8 was taken as a measure of CL degeneration (Milligan, 1974). The engraving tool was used to stimulate the voles, but without vibration. Females were killed on the day of examination and CL from each ovary were counted with the aid of a dissecting microscope. Several ovaries were fixed in formalin, embedded in paraffin wax, sectioned at $10 \mu \mathrm{m}$, stained with haematoxylin and eosin and examined microscopically to verify accuracy of CL counts.

Results. None of the 15 voles in Groups 1, 2 and 3 ovulated. Ovulation had taken place in 2 females in Groups 4 ( 5 and $6 \mathrm{CL}$ ) and 5 (2 and $5 \mathrm{CL}$ ). Corpora lutea in Group 5 females were fully developed, and no atypical luteal remnants were present. Thus, artificial stimulation with minimal stimulation from a male induced ovulation in $4 / 10$ females, and the CL from these ovulations seemed to be functional.

\section{Experiment III}

Fifteen Syrian golden hamsters received 30 insertions, each with $5 \mathrm{sec}$ of cervical 'tapping', using the syringe plunger (see Diamond \& Yanagimachi, 1968). Twelve females ( $80 \%$ ) became pseudopregnant (no post-oestrous discharge for 9-14 days).

\section{Experiment IV}

Method. The responses were compared of 32 F344/Mai laboratory rats (Rattus norvegicus) and 16 female roof rats $(R$. rattus), which were first-generation, laboratory-born offspring of wildtrapped animals. A single 10-sec vibratory vaginal-cervical stimulation was given with the engraver at different times, as shown in Table 2. An attempt was also made to mimic the male copulatory pattern: using the syringe plunger, 10 brief cervical taps were delivered with 1 min between stimulations and with a longer 10-sec stimulation 1 min later, to simulate ejaculation. After a 4-min rest period, an additional 3 series of 'intromissions' plus 'ejaculation' were given. Individual rats experienced 1-4 treatments but never the same treatment twice, and consecutive stimulations were separated by at least 2 weeks and 2 regular cycles.

Results. Laboratory rats showed a high incidence of pseudopregnancy in all groups, with maximal response to the pattern mimicking the male copulatory pattern $\left(\chi^{2}=7 \cdot 9, P<0.01\right.$ compared with all the shorter vibratory stimulations). Roof rats responded only to the pattern mimicking the male pattern, but at a lower rate than laboratory rats $\left(\chi^{2}=5 \cdot 6, P<0 \cdot 025\right)$. 
Table 2. Method (see text) and incidence of artificial induction of pseudopregnancy in Rattus

\begin{tabular}{|c|c|c|c|c|c|c|}
\hline Species & Group & $\begin{array}{l}\text { Stage of } \\
\text { cycle }\end{array}$ & $\begin{array}{c}\text { Time } \\
\text { (h) }\end{array}$ & $\begin{array}{l}\text { Method of } \\
\text { stimulation }\end{array}$ & $\begin{array}{l}\text { No. pseudo- } \\
\text { pregnant/no. } \\
\text { stimulated }\end{array}$ & $\begin{array}{c}\text { Mean } \\
( \pm \text { S.E.M. }) \\
\text { no. of days of } \\
\text { dioestrus }\end{array}$ \\
\hline \multirow[t]{6}{*}{ R. rattus } & 1 & Pro-oestrus & 15.00 & Vibration & $0 / 5$ & - \\
\hline & 2 & Pro-oestrus & 21.00 & Vibration & $0 / 5$ & - \\
\hline & 3 & Pro-oestrus & 21.00 & Tapping & $3 / 7$ & $11.0 \pm 1.5$ \\
\hline & 4 & Oestrus & 10.00 & Vibration & $0 / 5$ & - \\
\hline & 5 & Oestrus & 15.00 & Vibration & $0 / 5$ & 一 \\
\hline & 6 & Oestrus & 21.00 & Vibration & $0 / 5$ & - \\
\hline \multirow[t]{6}{*}{ R. norvegicus } & 1 & Pro-oestrus & 15.00 & Vibration & $4 / 5$ & $12 \cdot 8 \pm 1 \cdot 8$ \\
\hline & 2 & Pro-oestrus & 21.00 & Vibration & $1 / 5$ & 11.0 \\
\hline & 3 & Pro-oestrus & 21.00 & Tapping & $7 / 7$ & $14.9 \pm 1.7$ \\
\hline & 4 & Oestrus & 10.00 & Vibration & $3 / 5$ & $13.3 \pm 1.5$ \\
\hline & 5 & Oestrus & 15.00 & Vibration & $3 / 5$ & $13.3 \pm 1.7$ \\
\hline & 6 & Oestrus & 21.00 & Vibration & $4 / 5$ & $15.5 \pm 0.3$ \\
\hline
\end{tabular}

\section{Discussion}

Artificial vaginal-cervical stimulation was effective in inducing pseudopregnancy or ovulation in some females of all the species examined, and there were no apparent differences between induced and spontaneous ovulators in susceptibility to artificial stimulation. The non-domesticated species responded considerably less to artificial vaginal-cervical stimulation than did hamsters and laboratory rats. The 'standard' laboratory rat has probably been selected for high fecundity, amongst other factors, and is possibly 'super-responsive' to reproduction-related stimulation (Price, 1967). However, Boice (1972) reports that selective trapping of submissive $R$. norvegicus accounts, in part, for the relatively lower reproductive success of wild-trapped animals of that species. Natural selection, as it is presumed to act in the wild, must to some extent still operate in laboratory-bred animals, as only the dominant animals reproduce successfully. An extreme reaction to handling, may partly account for reproductive failure, possibly by an adrenally mediated antigonadotrophic effect (Richter, 1949; Boice, 1972). The differences in response of the laboratory rats in the present study and those of De Feo (1966) probably reflect procedural differences of the 2 studies (light-dark cycle, time and day of stimulation). We tried various times of stimulation because the time of ovulation in $R$. rattus is not known.

There was no obvious greater response to stimulation patterns which mimicked those typical of the species. For example, Peromyscus females which became pseudopregnant responded to a variety of stimulation conditions; laboratory rats showed the greatest response to, and $R$. rattus females responded only to, simulations of the male pattern, although these amounts of stimulation were greater than those applied by vibration. While it seems likely, therefore, that species-specific patterns are more effective than stimulation unrelated to the male pattern in inducing physiological responses in the female, the present data are not conclusive.

There was no indication that the response threshold of the female to artificial stimulation was related to conspecific male persistence in mating: male laboratory rats indulge in prolonged copulation (Beach \& Jordan, 1956) but some female $R$. norvegicus became pseudopregnant after just $10 \mathrm{sec}$ vibratory stimulation. Similarly, in non-domesticated species of Peromyscus, females which showed a physiological response did so to a variety of stimulation conditions and levels. No consistent facilitatory effect of copulation on the response to artificial stimulation was apparent in Peromyscus.

Microtus ochrogaster, like M. agrestis (Milligan, 1975), responded to artificial stimulation only when it was preceded by one intromission from a male. It is possible that pheromonal or contact 
factors are a necessary precondition to induced ovulation in these species or that different parameters of stimulation might give a higher incidence of response. Although $40 \%$ of $M$. ochrogaster ovulated after one intromission from a male when combined with artificial stimulation, and none did after the intromission alone, a $14 \%$ ovulation response to one intromission was reported in an earlier study (Gray et al., 1974). More animals should therefore be examined to assess the relative importance of limited copulation and of artificial vaginal-cervical stimulation in the induction of ovulation in this species. Microtus ochrogaster, unlike $M$. agrestis (Milligan, 1974), showed no evidence of a dissociation between ovulation and the formation of functional CL. As prairie voles require less copulatory stimulation than $M$. agrestis for induction of successful pregnancy (Gray et al., 1974; Milligan, 1975) another Microtus species with greater stimulation requirements is currently being examined in this context.

We thank Dr D. Q. Estep for trapping the wild Rattus rattus. A.McM.K. was supported by NICHD Postdoctoral Research Grant 5 F22 HD-01819-02, and the research was supported by Grant BMS75-08658 from the National Science Foundation.

\section{References}

BeACH, F.A. \& Jordan, L. (1956) Sexual exhaustion and recovery in the male rat. $Q . J l$ exp. Psychol. 8, 121-133.

Beach, F.A. \& Rabedeau, R.G. (1959) Sexual exhaustion and recovery in the male hamster. J. comp. physiol. Psychol. 52, 56-61.

BoIce, R. (1972) Some behavioral tests of domestication in Norway rats. Behaviour 42, 198-331.

CONAWAY, C.H. (1971) Ecological adaptation and mammalian reproduction. Biol. Reprod. 4, 239-247.

Davis, H.N., Gray, G.D., Zerylnick, M. \& Dewsbury, D.A. (1974) Ovulation and implantation in montane voles (Microtus montanus) as a function of varying amounts of copulatory stimulation. Horm. \& Behav. 5, 383-388.

Davis, H.N., Gray, G.D. \& Dewsbury, D.A. (1976) Maternal age and male behavior in relation to successful reproduction by female rats (Rattus norvegicus). J. comp. physiol. Psychol. (in press).

DE Feo, V.J. (1966) Vaginal-cervical vibration: a simple and effective method for the induction of pseudopregnancy in the rat. Endocrinology 79, 440.442.

DewsBuRY, D.A. (1974a) Copulatory behavior of California mice (Peromyscus californicus). Brain, Behav. Evol. 9, 95-106.

DewsBuRY, D.A. (1974b) Copulatory behavior of wildtrapped and laboratory-reared cactus mice (Peromyscus eremicus) from two natural populations. Behav. Biol. 11, 315-326.

Dewsbury, D.A. \& EsteP, D.Q. (1975) Pregnancy in cactus mice: effects of prolonged copulation. Science, N.Y. 18, 552-553.

Dewsbury, D.A. \& LANIER, D.L. (1976) Effects of variations in copulatory behavior on pregnancy in two species of Permoyscus. Physiol. Behav. (in press).

DiAmOND, M. (1970) Intromission pattern and species vaginal code in relation to induction of pseudopregnancy. Science, N.Y. 169, 995-997.

Diamond, M. \& Yanagimachi, R. (1968) Induction of pseudopregnancy in the golden hamster. $J$. Reprod. Fert. 17, 165-168.

ESTEP, D.Q. (1975) Copulatory behavior of Rattus rattus. Doctoral dissertation, University of Florida.
GraY, G.D. \& Dewsbury, D.A. (1973) A quantitative description of copulatory behavior in prairie voles (Microtus ochrogaster). Brain, Behav. Evol. 8, 437452.

Gray, G.D., Zerylnick, M., Davis, H.N. \& DewsBURY, D.A. (1974) Effects of variations in maie copulatory behavior on ovulation and implantation in prairie voles, Microtus ochrogaster. Horm. \& Behav. 5, 389-396.

KomISARUK, B.R. (1974) Neural and hormonal interactions in the reproductive behavior of female rats. Adv. Behav. Biol. 11, 97-130

LANIER, D.L., EsteP, D.Q. \& DewsbuRY, D.A. (1975) Copulatory behavior of golden hamsters: effects on pregnancy. Physiol. Behav. 15, 209-212.

LoNG, J.A. \& Evans, H.M. (1922) The oestrous cycle in the rat and its associated phenomena. Mem. Univ. Calif. 6, 1-137.

Milligan, S.R. (1974) Social environment and ovulation in the vole, Microtus agrestis. J. Reprod. Fert. 41, 35-47.

Milligan, S.R. (1975) Mating, ovulation and corpus luteum function in the vole, Microtus agrestis. $J$. Reprod. Fert. 42, 35-44.

OrsinI, M.W. (1961) The external vaginal phenomena characterizing the stages of the estrous cycle, pregnancy, pseudopregnancy, lactation and the anestrous hamster, Mesocricetus auratus Waterhouse. Proc. Anim. Care Panel 11, 193-206.

PRICE, E.O. (1967) The effect of reproductive performance on the domestication of the prairie deermouse, Peromyscus maniculatus bairdii. Evolution 21, 762-770.

Richmond, M. \& Conaway, C.H. (1969) Induced ovulation and oestrus in Microtus ochrogaster. $J$. Reprod. Fert., Suppl. 6, 357-376.

RICHTER, C. (1949) Domestication of the Norway rat and its implications for the problems of stress. Proc. Ass. Res. Nerv. Mental Disorder 29, 19-47. 